\title{
Vocational Didactics: Core Assumptions and Approaches from Denmark, Germany, Norway, Spain and Sweden
}

\author{
Michael Gessler* \\ University of Bremen \\ Institute Technology and Education (ITB) \\ Am Fallturm 1, 28359 Bremen, Germany \\ E-mail:mgessler@uni-bremen.de

\section{Lázaro Moreno Herrera} \\ Department of Education \\ Stockholm University \\ SE 10691 Stockholm, Sweden \\ E-mail: Larazo.moreno@edu.su.se \\ * Corresponding author
}

Received: 09 November 2015; Accepted: 10 December 2015; Published online: 15 December 2015

\begin{abstract}
The design of vocational didactics has to meet special requirements. Six core assumptions are identified: outcome orientation, cultural-historical embedding, horizontal structure, vertical structure, temporal structure, and the changing nature of work. Different approaches and discussions from school-based systems (Spain and Sweden) and dual systems (Denmark, Germany and Norway) are presented in this special issue. From an inside or national perspective, the solutions show a high cultural-historical dependency. From an outside or cross-national perspective, contingency and alternative possibilities become visible. The combination of both perspectives could enable continuity as well as innovation. This is the basic assumption of the presented collection about vocational didactics.
\end{abstract}

Keywords: Vocational Education and Training, Vocational Didactics, Denmark, Germany, Norway, Spain, Sweden

\section{Bibliographical notes:}

Dr Michael Gessler is a Professor at the Institute Technology and Education at the University Bremen, Germany. His research interests focus on transfer and innovation research in vocational education and training, vocational didactics, work-based learning, professional development and school-to-work transition.

Dr Lázaro Moreno Herrera is a Professor of Education with specialization in Vocational Education \& Training at the Department of Education at Stockholm University, Sweden where he leads the research group in the field. He has a $\mathrm{PhD}$ in Technology Education from Åbo Academy University, Finland. His research interests covers a variety of research areas within vocational education, including didactics, policy issues and comparative analysis. 


\section{Introduction}

Learning can be described as a process of four stages: input, process, output and outcome (Sloane and Dilger 2005). Input refers to the personnel, material, conceptual and environmental resources. The process stage refers to the delivery of learning opportunities. The output phase comprises the intended learning objecttives and the actual learning achievements. The outcome phase connects these achievements with the perspective of the use or application of what has been learned outside the actual learning setting.

\section{Outcome Orientation}

The term didactic, as the theory and practice of teaching and learning, comprises the input, process and output phases. However, the significance of what has been learned manifests itself in the outcome stage, especially in vocational education and training (VET). That is, where the application is put into practice. This leads to the first assumption:

(1) Outcome orientation: In VET, it is important to design learning opportunities, so that the learner can satisfy practical requirements in the workplace, on the one hand, and be able to shape his or her work as well as the work environment, on the other hand.

\section{Cultural-historical Embedding}

National vocational education and training systems pursue different aims and demonstrate different regulatory systems (governance). Greinert $(2004,2005)$ has studied the development of vocational training systems in Europe and identified three basic systems: (1) market-led systems, (2) politically controlled systems, and (3) collective regulated systems or mixed systems.

In market-led systems (e.g. United Kingdom), each individual is responsible for ensuring that he or she has a specific market value and is able to fulfil the expectations and requirements of the company. In the market principle, the development of skills is a personal investment which - in the event of employment - enables a return on investment. The problem with this model is that individuals must be able to anticipate the skills demanded by companies. Since the anticipation of future skills needs is difficult and risky, educational behaviour is geared towards current requirements to minimise the risk of bad investments. Investments in the development of skills that are not immediately usable tend not to be made, resulting in a skills shortage in the job market. In order to be able to respond quickly and flexibly to market-oriented training behaviour, educational programmes are modularised and equipped with certified powers. This leads to a multiplicity of programmes, which leads to further problems (quality control of programmes, confusion, etc.).

In politically controlled systems (e.g. Sweden, Spain and France), the political system protects the person from this form of commercialisation. While in the market system, the production factors of work and capital, that is, the individual (supply) and the business (demand), come uncontrollably into contact; in the political system, the relationship between an individual and business is created by the state. To achieve this, supply (skills) and demand (jobs) need to be balanced. To minimise the risk of a missing fit, a few basic vocational profiles are determined by the state, with the expectation that these be capable of responding to 
different types of demand. These basic profiles are based on an abstract economic need and are not targeted at a specific need. The contents are correspondingly abstract and theory orientated. This theory orientation is reinforced by the shape of the implementation: to exercise control over the supply side (skills development), vocational skills development is carried out in state-controlled schools, for which the state is responsible for financing. Despite this government control, there remains an individual risk at the interface with the employment system. The question of what skills a company specifically needs (and when) cannot be addressed by state control. The residual risk at the interface with the employment system also means that an attempt is made to climb onto the hierarchy logic of school certificates, with the result that academic qualifications be rated higher than vocational ones.

In mixed systems (e.g. Germany, Norway and Denmark), the state and industry cooperate with each other. In Germany, the government has delegated, for example, responsibility for the implementation of vocational training to the company, while the state itself is responsible for schooling, respectively vocational education. Training plans for vocational training are developed by representatives of industry under the supervision and moderation of the state. The curricula for school education are aligned with these occupational training plans. In contrast to the political system, VET programmes are geared towards the needs of the business. This situation requires a high level of commitment from businesses, which, in return, are entitled to shape vocational training and, thereby, are also responsible for co-financing. In the dual system of vocational training in Germany, about $70 \%$ of the total cost (school education and industry training) is borne by business. In an economic crisis, however, this leads to a tendency to reduce the number of training places, which is why, in addition to the dual vocational training system in Germany, fully school-based forms of vocational training (comparable to the politically shaped system) have been developed to compensate for this. The specifics of vocational training determine that it has an inherent value, but this also means that this is largely decoupled from the general and higher education system.

Following Busemeyer and Trampusch (2012), a fourth basic type can be identified. This type (the authors name it the "segmentalist skill formation system") does not exist in Europe, and it is in a process of erosion in the country of origin: Japan. The fourth basic type is characterised by a strong commitment of enterprises, but without government regulation. In this approach, the companies specify their needs, securing the necessary skills through internal training, and take over the financing. The motivation of the company to carry this commitment is the high specificity of skills and the expected return on investment for longer-term employment. The reference forms the market and especially the competition in which the companies find themselves. In times of crisis, companies reduce their exposure. Actually, the "live time contract" is under pressure. This crisis destroys the common set of basic values. Comparable with the mixed system, vocational training is decoupled from the general education system.

The four ideal types characterise the teaching and learning in vocational education and represent descriptions of textbook models. In fact, the systems are moving: work-based learning is entering politically shaped systems, individualbased market systems are increasing the skill levels, company-based market systems are shifting the responsibility to the individuals, and mixed systems are attempting to close the gap with higher education. In table 1, the characteristics of the four basic models are set out. 
Table 1: Ideal types of vocational training systems

\begin{tabular}{|l|l|l|l|l|}
\hline Principle & $\begin{array}{l}\text { School- } \\
\text { based } \\
\text { State System }\end{array}$ & $\begin{array}{l}\text { Company- } \\
\text { based Market } \\
\text { System }\end{array}$ & $\begin{array}{l}\text { Individual- } \\
\text { based Market } \\
\text { System }\end{array}$ & $\begin{array}{l}\text { Mixed } \\
\text { System }\end{array}$ \\
\hline Financing & State & Companies & Individual & $\begin{array}{l}\text { Companies } \\
\text { \& state }\end{array}$ \\
\hline Output & $\begin{array}{l}\text { Basic } \\
\text { qualifications }\end{array}$ & $\begin{array}{l}\text { Specific work } \\
\text { skills }\end{array}$ & $\begin{array}{l}\text { Partial } \\
\text { competencies }\end{array}$ & $\begin{array}{l}\text { Broad and } \\
\text { deep } \\
\text { competence }\end{array}$ \\
\hline Strengths & $\begin{array}{l}\text { Integrated } \\
\text { educational } \\
\text { system }\end{array}$ & $\begin{array}{l}\text { Engagement of } \\
\text { the companies }\end{array}$ & $\begin{array}{l}\text { Individual } \\
\text { engagement }\end{array}$ & $\begin{array}{l}\text { Balanced } \\
\text { social and } \\
\text { economic } \\
\text { interests }\end{array}$ \\
\hline Weaknesses & $\begin{array}{l}\text { Involvement } \\
\text { of the } \\
\text { companies }\end{array}$ & $\begin{array}{l}\text { Engagement of } \\
\text { the individuals }\end{array}$ & $\begin{array}{l}\text { Individual risks } \\
\text { and skill } \\
\text { shortages }\end{array}$ & $\begin{array}{l}\text { Decoupled } \\
\text { vocational } \\
\text { system }\end{array}$ \\
\hline $\begin{array}{l}\text { Actual } \\
\text { Challenge }\end{array}$ & $\begin{array}{l}\text { Integrate } \\
\text { work } \\
\text { experience }\end{array}$ & $\begin{array}{l}\text { Increase } \\
\text { individual } \\
\text { responsibility }\end{array}$ & $\begin{array}{l}\text { Reduce skill } \\
\text { shortages }\end{array}$ & $\begin{array}{l}\text { Reduce gap } \\
\text { with higher } \\
\text { education }\end{array}$ \\
\hline
\end{tabular}

Another example is the process of deregulation of politically controlled systems: since the 1960s, vocational education and training (VET) in Sweden has essentially been a matter of secondary schooling in state-run institutions. However, throughout the entire post-war period, the major forces of the Swedish industrial relations system - the organised labour movement and the employers' organisations - have played a decisive role in shaping VET policy. The 1970 Upper Secondary Education reform has been interpreted by some researchers as a sign of the unique strength of Swedish social democracy and the trade union movement. From this perspective, education reform was deemed to be one of the last products of the old struggle of organised labour for equal opportunities in education and against the old parallel system of general and vocational education, with the roads to further education/higher education being fenced for the majority of students. Indeed, a set of ordered relations between a strong, centralised state, ruled for a long time by Social Democratic governments, and very well-organised and strong actors at the level of industrial relations - generally termed the "Swedish model" - has been capable of defining a consensus in matters of education policy and translating it into political practice. After the 1990s, the Swedish educational system underwent a profound change in terms of decentralisation and deregulation. The earlier strong central regulation of school organisation, curricula and allocation of resources has been replaced by so-called goal governance, within the frames of which local actors (municipalities, schools, local industry and local unions, teachers, and so on) are to make decisions (Lundahl \& Sanders, 1998, p. 12; Nisson, 1994; Panikan, 2014).

Based on these different conditions and moving targets, a one-size-fits-all vocational didactic approach is not possible. This leads to the second assumption:

(2) Cultural-historical Embedding: A vocational didactic has to reflect the specific cultural character and changes of a VET system, and the inherent objectives, values and norms. 


\section{Horizontal Structure}

The third assumption to shaping a vocational didactic is posed by the occupations. Vocational training does not focus on education in individual subjects (mathematics, etc.), but rather the ability to act in a vocational domain. In Sweden, 12 vocational programmes are actual built up, while in Germany, 330 training occupations are distinguished (BIBB 2015). Moreover, the system is changing: 1971 existed in Germany e.g. 606 and in 1985432 training occupations (BMBF 1985). Taking the vocational programmes in Sweden and the training occupations in Germany as an example into account, 12 or 330 vocational didactics are required. Which type of access is applicable and which number is adequate? In contrast to the largely stable and clearly structured subjects in general education (e.g. mathematics and languages), the domains in vocational education and training are diverse, has no generally accepted horizontal structure and are subject to constant change. This leads to the third assumption:

(3) Horizontal structure: A vocational didactic has to reflect this normativity and has to be, nevertheless, aligned with a professional domain.

\section{$5 \quad$ Vertical Structure}

A further assumption is also grounded in the occupations. While in general education, levels apply in principle to all pupils in the same year (this is the basic assumption of the Programme for International Student Assessment and the idea of international comparability), occupations have a vertical structure, such as: (1) unskilled or semi-skilled activities, (2) professionally oriented activities, (3) complex specialist activities and (4) highly complex activities. Vocational didactics have to take different requirement levels into account. This leads to the fourth assumption:

(4) Vertical structure: A vocational didactic has to be aligned with the corresponding requirement levels for the respective occupation (e.g. semi-skilled activities, professionally oriented activities and complex specialist activities).

\section{Temporal Structure}

Vocational education and training consists (at least) of vocational orientation, initial vocational education and training, and continuing vocational education and training. This leads to the fifth assumption:

(5) Temporal structure: A vocational didactic has to be aligned with the respective objectives pursued in a particular phase of (work) life: vocational orientation, vocational development and education, and further vocational training and re-orientation.

\section{The Changing Nature of Work}

VET is related to the conditions of work and should therefore prepare people for changing conditions and the nature of work. The actual ILO Report (2015) mentions the following trends and challenges: 
- Employment relationship: "In short, the standard employment model is less and less representative of today's world of work since fewer than one in four workers is employed in conditions corresponding to that model" (p. 13).

- Poverty and social exclusion: "Temporary and informal workers, part-time workers and unpaid family workers, many of whom are women, are also disproportionately affected by poverty and social exclusion" (p. 14).

- Global supply chains: "Approximately one in five workers is estimated to work in global supply chains. (...) The intense competitiveness and short product cycles in some global supply chains also feed down to workers' contractual arrangements and working hours" (p. 15).

This leads to the sixth assumption:

(6) The changing nature of work: A vocational didactic has to be oriented not only towards the standard employment model and standard occupations and jobs, but also towards the changing nature of work, the risk and fact of poverty and social exclusion, and the reality of global supply chains.

This analysis is not a declaration of bankruptcy. What is needed is rather a discourse about solutions. This special issue is an attempt to focus approaches and insights that originate from different countries with either school-based (Sweden and Spain) or dual-based systems (Norway, Denmark and Germany).

Sweden: As highlighted already, the Swedish VET system has had a strong school-based design since the 1970s. This, to a great extent, explains the existence of an interest in the development of a didactics able to cope with the complexities of a learning process that takes place both in what we can term "traditional classroom settings" and in workshops. Vocational didactics is an important subject in the training of vocational teachers in Sweden, with a focus on the learning process and particular attention towards the understanding and development of vocational knowing.

An article by L. Moreno Herrera highlights key conceptual aspects and presents research that is of relevance in the discussion about didactics in the Swedish context. Didactics is depicted as an intricate field with epistemological and ontological grounds that sometimes intersect or diverge. Research on didactics in German, Nordic and French contexts is discussed in the search of transitions and diversity in the various approaches expecting to contribute to the discussion about prospects and shortcomings in the development of a didactics for vocational education and training. The contribution by Moreno Herrera attempts to suggest lines of development and encourage discussions about the further research needed (Moreno Herrera 2015).

Spain: Spain has a school-based system of formal vocational education after successful completion of compulsory schooling, and that system is complemented by a non-formal vocational training system (which, in fact, works as a market) that supplies training for the many youngsters that have left the school system without successful completion as well as for large numbers of the unemployed population; there is a particular focus on those who are signalised as groups at risk of social exclusion. Work experience in companies was allowed in 1974, developed for the first time in 1984, and has been made compulsory in all formal vocational education since 1990, the very same year in which a tripartite system 
(administration, employer representatives and trade union representatives) was established to design the mandated curriculum for each of the occupations that the school-based system offers. Vocational education of VET teachers and trainers has not been an issue for many years, and only recently has it been given proper attention, in the belief that mastery of content does not guarantee appropriate knowledge transmission and delivery.

An article by F. Marhuenda-Fluixá and A. Ros-Garrido explains the context in which VET has developed in the past 40 years in Spain, when the country left authoritarian dictatorship behind and entered democracy, and it also shows the development of the field of didactics throughout these decades. The enrichment of academic debates has opened much space for addressing teaching and training practices as an issue, not only of methodological choice but also of curriculum design and development and of deliberative practice, where research has contributed towards advancing the field itself. Without neglecting its normative attempt, didactics in Spain has incorporated both empirical as well as reflective dimensions, with the attempt to empower teachers and trainers mainly as a professional body. What this implies nowadays is that the country faces large figures of long-term unemployed of different ages, where the notion of a career is posing new demands for didactical approaches to VET (Marhuenda-Fluixá and Ros-Garrido 2015).

Norway: Norway is characterised as a dual or mixed system, with two years of school-based education followed by two years of work-based training as the main model $(2+2)$. The system, built upon the tripartite cooperation principle, has been established at both national and regional levels, involving both employers' and workers' unions. Vocational didactics is a central part of vocational teacher education, underpinning the learning processes connected to learning a trade, as the trainers undergo short courses while getting to know their role and responsibilities. Training offices owned by companies (employers) are a strong actor in the workbased part of VET and in the transitions between school and work.

An article by $\mathbf{H}$. Nore questions a strict regulation of learning outcomes at the different levels of VET, as well as the different learning arenas. Learning arenas become even more of a hybrid than the former $2+2$ model, as learners become codesigners of their learning paths, and teachers alone cannot meet the learners' need for guidance to knowledge and skills in a broad variety of trades. E-portfolios increase in use but point in different directions: towards quality control of outcomes or a cooperation tool for designing and facilitating individual learning processes and even empowerment of the learner (Nore 2015).

Denmark: As described, the VET system in Denmark is dual and includes practice as well as school. Basically, the admission to VET is free. Vocational college teachers in Denmark are facing complex challenges. They have to adapt their pedagogy to pupils characterised by great diversity; some students are from backgrounds with no tradition for education and have social or academic problems, and schools struggle with high drop-out rates. For such reasons, a new education programme, Diploma of Vocational Pedagogy, has recently been implemented in Denmark to improve didactics at VET colleges. The diploma is an important step in the realisation of a recent reform of Danish VET, which aims to upgrade vocational teachers' didactical skills and improve their ability to adapt their teaching to the very diverse groups of pupils at VET colleges. It places increased demands on vocational teachers in terms of their ability to reflect on pedagogy and didactics. 
An article by H. Duch and K. E. Andreasen discusses and analyses the implementation of the reform in the light of such intentions by focusing on students' experiences and development in seeking the Diploma of Vocational Pedagogy. Based on empirical data from a research project, the article thus focuses on the input and process stages of didactics and analyses the output and outcome stages. The analysis is based on data from focus group interviews conducted in spring 2015 with teachers from two vocational colleges. In teachers' reflections on their own and fellow course participants' potential and progress, they refer to the pedagogical and didactical theories to which they are introduced through attaining the diploma. These processes influence and shape the way in which they understand themselves and their reflections on pupils, didactics and pedagogy. The analysis uncovers several factors that can be expected to complicate the improvement of VET didactics (Duch and Andreasen 2015).

Germany: The VET system in Germany consists of different levels (a lower, an intermediate, an advanced and an academical level) and forms (school-based or dual). The curricula are either scientific-oriented (mostly in school-based configurations) or work-oriented (mostly in dual-based configurations). The academical level is also offered either school-based in Universities of Applied Sciences (with internships in companies) or dual in Universities of Cooperative Education (the student has in the company the status of an apprentice).

In an article by $\mathbf{M}$. Gessler and $\mathbf{F}$. Howe, a curricula and training approach is presented which is based on the experiences of skilled workers: what are those people doing when handling a task, how are they acting, what work objects and tools are they operating with, and what requirements do they have to be aware of? To answer these kinds of questions, the real work in practice must be explored. The next step comprises developing as a teacher team a work-based learning situation for the classroom. Both topics are addressed in the article. The key proposition of the authors is as follows: if work orientation is wanted (in dual as well as schoolbased configurations), the content and practice gap between the world of work and the world of education has to be closed (Gessler and Howe 2015).

In the presented approaches, the border between work and education is addressed; nevertheless, the answers are different. From an inside perspective, the solutions show a high cultural-historical dependency. From an outside perspective, contingency and alternative possibilities become visible. The combination of both perspectives could enable continuity as well as innovation. This is the basic assumption of the presented collection. 


\section{References}

BIBB Bundesinstitut für Berufsbildung (2015). Datenreport zum Berufsbildungsbericht. Informationen und Analysen zur Entwicklung der beruflichen Bildung. Bonn: BIBB.

BMBF Der Bundesminister für Bildung und Wissenschaft (1985). Berufsbildungsbericht 1985. Bad Honnef: Bock.

Busemeyer, M., \& Trampusch, C. (2012). The Comparative Political Economy of Collective Skill Formation. In M. Busemeyer, \& C. Trampusch (Eds.), The Political Economy of Collective Skill Formation (pp. 3-38). New York: Oxford University Press.

Duch, H., \& Andreasen, K.E. (2015). Reforming Vocational Didactics by Implementing a New VET Teacher Education in Denmark: Tensions and Challenges Reflected in Interviews with Vocational College Teachers. International Journal for Research in Vocational Education and Training, 2(3), 252-160.

Gessler, M., \& Howe, F. (2015). From the Reality of Work to Grounded WorkBased Learning in German Vocational Education and Training: Background, Concept and Tools. International Journal for Research in Vocational Education and Training, 2(3), 214-234.

Greinert, W.-D. (2004). European vocational training systems - some thoughts on the theoretical context of their historical development. European Journal Vocational Training, 32, 18-25.

Greinert, W.-D. (2005). Mass vocational education and training in Europe. Classical models of the 19th century and training in England, France and Germany during the first half of the 20th. Cedefop Panorama series, 118. Luxembourg: Office for Official Publications of the European Communities.

Lundahl, L., \& Sander, T. (1998). Vocational Education and Training in Germany and Sweden: Strategies of control and movements of resistance and opposition. Umea, Sweden: Thematic Network on Teacher Education in Europe.

Marhuenda-Fluixá, F., \& Ros-Garrido, A. (2015). What Sense Can We Make of the Possibility of Vocational Didactics? An Approach from the Spanish School-Based System Complemented by Non-Formal Vocational Training. International Journal for Research in Vocational Education and Training, 2(3), 170-181.

Moreno Herrera, L. (2015). Transitions and Diversity in Didactics: An Exploration Searching for Implications for Vocational Education and Training. International Journal for Research in Vocational Education and Training, 2(3), 161-169.

Nilsson, A. (1994). Visions and Labour Demand. The Planning of Vocational Education for the Swedish Manufacturing Industry 1950-1993. Lund: Department of Economic History.

Nore, H. (2015). Re-Contextualizing Vocational Didactics in Norwegian Vocational Education and Training. International Journal for Research in Vocational Education and Training, 2(3), 182-194.

Panican, A. (Ed.). (2014). Yrkesutbildning för morgondagens arbetsliv. Stockholm: Dialogos Förlag.

Sloane, P.F.E., \& Dilger, B. 2005: The competence clash - Dilemmata bei der Übertragung des 'Konzepts der nationalen Bildungsstandards' auf die berufliche Bildung.bwp@,Berufs- und Wirtschaftspädagogik online, 8, 1-32.

ILO International Labour Organization (2015). World Employment Social Outlook: The changing nature of work. Geneva: International Labour Office. 